\title{
The moral economy of the pharmaceutical industry: Legitimising prices
}

\author{
Joan Busfield \\ University of Essex, UK
}

Joan Busfield, Department of Sociology, University of Essex, Wivenhoe Park, Colchester CO4 3SQ, Essex, UK. Email: busfj@essex.ac.uk

\begin{abstract}
The practices of pharmaceutical companies have been widely criticised by researchers and investigative journalists, yet their conduct has mostly escaped significant moral opprobrium from the wider public, health professionals and governments. This article examines one reason for this by exploring the techniques companies use when seeking to justify and legitimise their conduct - legitimising techniques that help to render their failures to adhere to accepted standards less visible. It explores these techniques by examining four cases involving pricing where the companies' conduct has, nonetheless, been questioned. It is divided into three parts. The first looks at the various publicly_stated standards that provide the moral context for the industry's activities. The second examines four cases, each involving pricing, where companies' prices have been challenged as morally unacceptable, each leading to a US Government investigation. These provide a means of exploring how companies seek to justify their actions in order to maintain the appearance of conformity to accepted moral standards. The third considers some reasons why the industry's efforts at legitimation have considerable force. The analysis shows not only the character of the claims made by pharmaceutical companies in defence of their practices - claims about the health benefits of the medicine, access to it, and research and development costs, which are all often exaggerated. It also shows why the companies' legitimising tactics are typically effective.
\end{abstract}

\section{Keywords}

bioethics, health policy, technology in healthcare 
Criticisms of the activities and practices of the pharmaceutical industry by researchers and investigative journalists have become commonplace. These include wide-ranging critiques, such as Marcia Angell's (2005) The Truth about Drug Companies: How they deceive us and what to do about it and Ben Goldacre's (2012) Bad Pharma: How drug companies mislead doctors and harm patients. They also include more specific critiques, such as David Healy's (2012) Pharmageddon, which examined the limitations of drug trials and companies' failure to publish negative results, and Ray Moynihan and Alan Cassels' (2005) Selling Sickness: How drug companies are turning us all into patients, which analysed how companies' marketing is used to transform complaints into sicknesses.

Such books and other papers have scrutinised many of the industry's practices - one dominated by large-scale companies with a global reach, mostly based in the United States and Europe - analysing how many, when examined in detail, are morally dubious, putting profits at the forefront and the interests of patients well behind. An implicit contrast often underpins such analyses: between the assumptions lay people commonly make that medicines, particularly those prescribed by doctors, are designed for the benefit of patients, and the reality of the highly commercial orientation of companies, whose focus seems typically to be more on revenue maximisation than health maximisation.

Yet, despite such criticisms the industry has continued to engage in various morally dubious practices. How has this been possible? In order to begin to answer this question, it is necessary to examine in some detail the arguments companies put forward to defend their practices and also consider the reasons why they have considerable force. Since the range of practices subjected to criticism is extensive, the article focuses on one contested area pricing - examining the ways companies attempt to legitimise high prices, in order to demonstrate their adherence to the moral standards the industry claims to uphold.

The article is divided into three parts. The first looks at the industry's various published standards. The second focuses on four cases where prices have been pushed up to levels where they have been publicly challenged and then subjected to US Government investigation intended to explore the factors involved and the possible need for government legislation. Such investigations put the companies at reputational risk, and mean that they are forced to defend their prices, so enabling a careful examination of the justifications offered. The cases are presented in chronological order of the Congressional investigation. First, is the price rise for Gilead Sciences' Sovaldi, a drug to treat hepatitis C, investigated in December 2015. Second, is that by Turing Pharmaceuticals for Daraprim, a treatment for toxoplasmosis, heard in January 2016. Third, are the rises for Valeant's Nitropress and Isuprel for heart disease, examined in April 2016. Finally, there is the price set for Mylan's EpiPens for anaphylaxis, investigated in September 2016. The third section identifies some reasons why the industry's legitimising efforts have considerable force and can be difficult to challenge effectively.

\section{Theoretical frameworks}

The article draws on two approaches chosen for the way in which they help to illuminate how the industry seeks to legitimise its practices. First, it uses EP Thompson's (1971) development of the concept of 'moral economy' - the social norms and obligations within which economic activity occurs (see also Morris, 2016). Thompson (1971) employed the term when examining the activities of the crowd in 18th-century food 'riots', using it as a counterpoint to a narrow view of individuals as economic actors, which obliterates 'the 
complexities of motive, behaviour, and function' (p. 78). He argued that it was essential to move away from a simple economic analysis that could not alone provide an adequate explanation of the crowd's actions. Instead, it was necessary to locate their activities over the price of bread within the context of the society's moral assumptions as to what were and were not considered legitimate practices. The need to explore the moral context of economic activity also applies to the pharmaceutical industry. Pharmaceutical companies are economic actors, but they exist in a universe of social norms and obligations and, wherever they operate, are expected to follow certain moral standards that are widely accepted across Western societies, which can conflict with their economic objectives.

Second, the article draws on the classic work of Gresham Sykes and David Matza (1957) on 'techniques of neutralization' deployed by juvenile delinquents to rationalise their departures from the dominant normative code. Two are of particular interest. The first is 'denial of injury', which questions whether any harm has resulted from the purported wrongdoing. The second is 'denial of responsibility', which justifies the infraction by reference to forces outside the individual's control. Their analysis provides a useful framework for considering how actors 'bend' norms and values in seeking to ensure that their actions are deemed legitimate. However, given the character of the techniques pharmaceutical companies use as tactical devices in debates over their practices, they are here termed 'legitimising techniques'.

\section{Methods}

The first section of the article draws on various documents specifying drug approval agencies' legal requirements when assessing drugs for release onto the market: pharmaceutical associations' formal codes of practice and pharmaceutical companies' Corporate Social Responsibility (CSR) statements. The four cases that constitute the article's empirical core were selected because all led to investigations between December 2015 and September 2016 by US Government committees concerned about the significant price rises involved. The testimonies to and reports of these investigations provide the empirical basis of the second section, which also draws on company statements to the media. The final section makes use of a range of published research on the industry.

\section{Standards of conduct}

The pharmaceutical industry is subject to government regulation in certain areas, most notably in relation to standards of safety and efficacy, and the official regulatory requirements that must be met for a drug to be released onto the market, which constitute one set of obligations of the moral economy that frames the industry's activities. These legally enshrined requirements are specified by drug-approval agencies, some cross-national such as the European Medicines Agency (EMA) and some national like the influential US Food and Drug Administration (FDA). Many were introduced or strengthened following the thalidomide scandal of the early 1960s (Abraham, 1995); some have been loosened in recent years, partly because of moves towards international harmonisation (Abraham and Reed, 2001) and partly under pressure from the industry, and from patients and families wanting speedier access to potentially beneficial medicines (Davis and Abraham, 2013). The requirements to establish a medicine's safety and efficacy before it is approved for public use are grounded in the moral standards and values of society. That to assess safety is based on assumptions about the value of human life and health and the avoidance of harm, and that on efficacy is a recognition that a drug's benefits should be established before it is approved, not least because all medicines have 'side effects' - negative consequences as well as any 
positive ones. The aim is to ensure that the health benefits exceed the harms. However, meeting these requirements typically pushes up research and development (R\&D) costs that, as we shall see, feature heavily in justifications of pricing.

Second, industry associations have developed codes of conduct that companies are expected to follow. The Code of Practice of the International Federation of Pharmaceutical Manufacturers and Associations (IFPMA), an association of research-based companies founded in 1968, is one example; others are similar. IFPMA's (2012) latest code has eight guiding principles described as basic standards, beginning with 'the healthcare and wellbeing of patients are the first priority for pharmaceutical companies'. Others deal with the provision of accurate data, and the promotion of drugs. None specifically mention prices, but the first is highly relevant to pricing.

Complaints about a breach of the code can be made to IFPMA and are examined by a threeperson adjudication group the Association selects. If upheld, the company must produce a compliance statement regarding future conduct and the outcome is made public.

Third, pharmaceutical companies now regularly produce CSR statements that are increasingly required under UN business and human rights frameworks, and European Union (EU) directives. These list areas where the company asserts it is taking action, supplementing and helping to reinforce the industry's ethical claims. They include facilitating access to its medicines, something significantly affected by medicine prices and mentioned in most pharmaceutical CSR statements, along with matters such as ensuring environmental sustainability, and following ethical business practices in relation to employees and trial participants.

These then are some of the moral standards companies are expected and claim to follow while pursuing their economic objectives. Taking the issue of prices, what justifications do companies use in an effort to maintain the appearance of conformity to them, even against contrary evidence?

\section{Legitimising prices}

\section{Case 1: Gilead Sciences and Sovaldi}

Since the 1950s, leading pharmaceutical companies have mostly focused on developing patented drugs for which they can charge relatively high prices by virtue of the market exclusivity provided by the patent, currently 20 years. While patenting typically occurs some years before a drug is approved, the United States and Europe now provide exclusivity extensions to help to cover the time taken by development and approval. Companies can also seek patent extensions by identifying a new method of delivery, a new therapeutic use, or agreeing to test it on children (Gupta et al., 2010). And major companies sometimes pay smaller ones to delay introducing generic competitors. For example, in 2016 British-based GlaxoSmithKline was fined $£ 38$ million by the UK Competition and Markets Authority for the anti-competitive practice of paying two smaller companies (given smaller fines) to delay introducing generic competitors to its antidepressant paroxetine (GOV.UK, 2016).

Until the 1990s, the patented medicines produced by leading companies were primarily chemically synthesised new molecular entities. Especially profitable were drugs that could be prescribed to large numbers for lengthy periods (Dumit, 2012), like the newer anti- 
depressants and cholesterol-lowering statins, some becoming 'blockbusters' with annual sales of US\$1 billion or more. A company holding the patent for one or two was usually financially secure until they expired. Profitability was one reason for the practice of developing 'me-toos' - drugs just sufficiently distinct that a new patent could be obtained but with little therapeutic gain (Light and Lexchin, 2012).

More recently, innovation has come in the form of patented medicines based on biological substances and processes, often administered by injection. These new-generation 'biologics', many of which have been developed for less common conditions, some previously neglected, are often sold at very high prices that can attract adverse publicity. Indeed, even if the market is limited, new drugs extending life, albeit only for 2 or 3 months, or reducing symptoms, provide opportunities for companies to make large profits by charging exceptionally high prices. In the United States, for instance, one treatment for advanced melanoma was priced at US $\$ 120,000$ for the standard course of four doses (Fellner, 2012: 509).

The first case examined here concerns a new biologic marketed by Gilead Sciences, a USbased company established in 1987 focusing on anti-viral products, and so far one of only two biotechnology companies to reach the list of the top 15 pharmaceutical companies globally (IGEA Hub, 2017).

In January 2012 Gilead, concerned about the lack of new products in its pipeline, completed an US\$11.2 billion acquisition of Pharmasset, another US-based biotechnology company. Pharmasset was developing a drug, sofosbuvir, to treat hepatitis $\mathrm{C}$ (also termed HCV), which was doing well in trials, and accordingly was an attractive proposition for Gilead, not least because there were around 5 million US individuals with hepatitis $\mathrm{C}$. The drug was approved by the FDA in 2013 and marketed as Sovaldi by Gilead, with a second-stage product combining sofosbuvir and ledispavir marketed as Harvoni. The US price eventually set for a single 12-week course of Sovaldi was US\$84,000. This price, the public disquiet about it and the potential impact on US healthcare budgets, including Medicaid and Medicare, led to the US Senate's Committee on Finance's investigation and its 2015 report.

The investigation was based on extensive documentation Gilead provided at the Committee's request, with detailed information about pricing decisions, including records of their Global Pricing Committee. Since companies' data on pricing is typically confidential, this documentation is particularly fascinating. The report and the documents, mostly from Gilead, ran to about 2000 pages, though the Committee noted that even then Gilead failed to provide all those requested.

How did Gilead seek to legitimate Sovaldi's high price? Its task was made more difficult by the fact that the documents showed that prior to its acquisition, Pharmasset had planned to charge US\$36,000 for the standard 12-week treatment - a high price, but less than half of Gilead's eventual US\$84,000, though Gilead subsequently claimed that Pharmasset had never intended to market it for US\$36,000 (Alton, 2016). The Committee's July 2014 letter to Gilead's chief executive also noted that in Egypt a course was offered for US\$900, 'a 99 percent discount on the price in the U.S.' (Senate Committee on Finance, 2015: 129), definite evidence that the US price did not reflect company costs. Indeed, the report concluded that the main objective of Gilead's pricing decisions was to maximise revenue.

Gilead used three key arguments to justify Sovaldi's price. The first was to argue that the 'cost per cure' was reasonable because the drug was such a clear improvement over existing 
competitors. Put another way, they contended that its effectiveness justified its price. This argument is widely used across the industry in different forms and addresses IFPMA's (2012) principle that 'The healthcare and well-being of patients are the first priority for pharmaceutical companies' (p. 2). More generally, it is an argument that the price of a treatment can be justified by its health benefits. In Sovaldi's case, the evidence did indicate the drug performed well and was generally effective. Indeed, Roy and King (2016) in a BMJ article critical of its price described the drugs as a breakthrough in hepatitis $\mathrm{C}$, 'offering cure rates of over 90\%'. Gilead's cost per cure argument was, however, constructed in terms of what price the market would bear, however high, and not whether it was justified by the development and production costs or would reduce access. In response to Roy and King's (2016) criticism, Gregg Alton, Gilead's Executive Vice-President, claimed,

we stand behind the pricing of our therapies because of the benefit they bring to patients and the significant value they represent to payers, providers and our entire healthcare system by reducing the long-term costs associated with managing chronic $\mathrm{HCV}$.

He also contended that, 'In two and a half years, more than one million HCV patients have been treated with our HCV therapies throughout the world. We believe we have cured more patients in this timeframe than in the previous 20 years' (Roy and King, 2016), though no source was given to support this claim.

However, Gilead's second justification did relate to access - that the price did not restrict access because of the extensive price reductions provided. Here, we see Sykes and Matza's denial of injury argument. Again this addresses IFPMA's principle that the healthcare and well-being of patients are companies' first priority, and also CSR statements' claims about facilitating access to medicines - Gilead's (2018) states it has a programme for advancing access to its products in the United States. Alton (2016) put it like this: 'Enabling patient access to our HCV therapies is a top priority for Gilead'. He then described how the company provided discounts:

The WAC [wholesale acquisition cost] then serves as the basis for negotiated discounts and rebates between manufacturer and payers as competition develops in a therapeutic space. Mandatory discounts are also given to payers like Medicaid. This process is standard in the industry and in this case most payers receive substantial discounts off the list price with the steepest discounts going to government payers like Medicaid and the VA [Veterans Adminstration]. Both the VA and Medicaid, for example currently receive discounts in excess of 50\% on Harvoni. (Alton, 2016)

Claims that high prices do not restrict access because of extensive discounts is a standard legitimising technique pharmaceutical companies use, particularly in the United States, because of the character of its healthcare system. In the case of Sovaldi, the Gilead documents show the company was concerned that the price should not be seen as undermining access. Indeed, they hired IMS, a US company providing information and services to the healthcare industry, to help them 'determine the access-optimising price point for its novel HPV therapy sofosbuvir in support of the brand's launch' (cited in Senate Committee on Finance, 2015: 37). IMS contacted likely US payers - such as managed Medicaid groups, the VA, insurance companies, pharmacy benefit managers and those offering other healthcare plans, telling them about the drug's benefits and discussing its value, without identifying the company. IMS suggested that a price of US\$80,000US $\$ 90,000$ was probably acceptable - hence the US $\$ 84,000$ price Gilead adopted. However, 
Gilead's concern about access was double-edged since ensuring adequate access is not only important to the health of individuals, but also to sales volume since high prices can reduce sales. Determining the point of revenue maximisation was not easy, the reason they consulted IMS.

Gilead's third justification for Sovaldi 's price - the costs of research and development - is a common legitimising technique citing the high costs of identifying, standardising and testing new medicines. In this Gilead both invoked the constraint of R\&D costs, with the implicit denial of responsibility for high prices, and also affirmed possible future health benefits. Alton in his 2016 response mentioned the industry's investment of US $\$ 50$ billion in the development of hepatitis C drugs between 1994 and 2014, though again gave no source for this figure. He also claimed that the majority failed in the early stages, with only 1.9 per cent making it to market, suggesting the high level of risk, wastage and cost involved in drug development. Furthermore, he mentioned the risk of purchasing Pharmasset when it had only carried out phase 2 studies on two smaller patient groups, implying that Gilead did not know whether Sovaldi would be effective on the largest group with hepatitis C. However, the Senate Committee noted that despite such claims, Gilead was confident at the time in 'sofosbuvir's ability to gain FDA approval' (Senate Committee on Finance, 2015: 16) - a confidence they considered stemmed in part from the months spent studying the global market for the drug and potential revenue streams. They also noted that Gilead had not provided the complete R\&D costs for Sovaldi, conflating them with those for Harvoni and another related compound. Interestingly, Alton further emphasised that the bulk of the R\&D costs were paid for by the two companies and did not depend on public funding, apart from a tax incentive to Pharmasset of around US $\$ 0.25$ million. As the industry has often depended heavily on publicly funded academic research (Kinch, 2016), Alton clearly considered he needed to indicate that this did not apply to Sovaldi.

A focus on $R \& D$ costs, which though often exaggerated is relevant in most instances and so can be defended in general terms, deflects attention away from other spending that can contribute to the pressure for high prices. In Gilead's case, one was the high pay of the chief executive, whose salary between 2009 and 2015 was the first or second highest among the pharmaceutical companies listed in Standard and Poor's 500 (Lazonick et al., 2017).

\section{Case 2: Turing Pharmaceuticals and Daraprim}

Charging high prices for out-of-patent medicines, branded or unbranded, is a relatively recent phenomenon. One such case that generated widespread public attention was Turing Pharmaceuticals' steep price rise for an off-patent drug, branded as Daraprim. Daraprim is primarily used, combined with another drug, to treat toxoplasmosis, a parasitic infection mostly asymptomatic in Western countries but when acute, dangerous for unborn children and those with a compromised immune system, such as individuals with AIDS or undergoing chemotherapy.

In August 2015, Turing purchased the US and Puerto Rican rights to Daraprim, for US $\$ 55$ million from a small US pharmaceutical company, Impax. Turing, with headquarters in Switzerland, was founded in February 2015 by Martin Shkreli, a US hedge-fund operator, who rapidly raised the drug's US price from US\$17.63 to US\$750 per pill (Turing Pharmaceuticals, 2016). 
Pyrimethamine, its chemical name, had been developed in the 1940s by the British Burroughs-Wellcome, in use since 1953, and off-patent since the 1970s. BurroughsWellcome, like many pharmaceutical companies towards the end of the century, was involved in several mergers, with Glaxo in 1995, and then SmithKline Beecham in 2000, creating the multinational GlaxoSmithKline, which still had the rights to the Daraprim brand. Such companies usually focus on patented drugs that generate higher profits, rather than nonpatented drugs, though a brand name like Daraprim, protected through trademark registration, can bestow something of a market advantage over a generic (unbranded) product. In this case, however, the market for the drug in Western countries was small. Presumably this is why in 2010, GSK sold the US and Puerto Rican brand rights to CorePharma, a subsidiary of Tower Holdings, a small US company, assuming the drug would no longer generate much profit.

In February 2015, Impax acquired Tower Holdings and sold the US brand rights to Daraprim, along with some other drugs, to Shkreli's Turing to help fund the acquisition. Impax had raised Daraprim's wholesale price from US $\$ 13.55$ per pill to US $\$ 17.63$ during its brief ownership of the rights (Turing Pharmaceuticals, 2016). Turing's raising of the price to US\$750 per pill made it far higher than that charged elsewhere in the world. In the United Kingdom, where GSK retained the brand rights, the price of a 30-tablet pack was $£ 13$ - clear evidence that Turing's price was exceptionally high.

Usually when a drug comes off-patent, competition leads to a marked price reduction. The main reason Turing could contemplate such a price was that it recognised it had a US monopoly for the branded drug and was unlikely to face any competition, since the market was small and the costs of securing FDA approval for a generic competitor was relatively high.

Such a sharp rise in the price of an unpatented drug was highly unusual, attracted global media attention and led to a summons to Shkreli to appear before the US House of Representatives Committee on Oversight and Government Reform. Shkreli initially refused to attend (by then he had been charged with securities fraud relating to his hedge fund activities) but was subpoenaed. However, when he eventually appeared he refused to testify, citing the Fifth Amendment.

Given the furore over Turing's 'price-gouging' - a rise in price judged unfair and unreasonable - it is important to examine how the company attempted to justify the increase. Although Shkreli refused to answer the Committee's questions, he made some comments to the media and his answers reveal two of the key legitimising techniques already mentioned. First, he commented, 'If there was a company that was selling an Aston Martin at the price of a bicycle, and we buy that company and we ask to charge Toyota prices, I don't think that would be a crime' (cited in Ramsey, 2015). Here he claims the value of the product is considerable, and justifies the price - an affirmation of its health benefit. This is the justification Gilead used when seeking to defend Sovaldi's price, with the suggestion here that Daraprim's price could reasonably have been even higher. Price, Shkreli suggested has less to do with the cost of developing and producing the drug than its value to patients.

Shkreli also deployed the second legitimising technique Gilead had used, addressing the principle that companies should make patients' healthcare and well-being their first priority something threatened by high prices which usually reduce access. He asserted that half the drugs were given away free and that this programme would be expanded (Ramsey, 2015) - a denial that price was restricting access - Sykes and Matza's denial of injury. Significantly, 
given the public furore, and presumably feeling vulnerable on this matter, Turing then halved the US price, thereby accepting it was too high.

Because of Shkreli's refusal to testify, Turing's testimony was given by its Chief Commercial Officer, Nancy Retzlaff, who had previously worked in several multinational pharmaceutical companies. In her testimony, submitted when she appeared before the Committee, Retzlaff began with the issue of patients' health and well-being and whether access was restricted by Daraprim's price. Like Shkreli she used the same denial of injury argument, claiming access was not limited. Access, she asserted, was one of the company's business goals and she outlined how most patients were able to obtain Daraprim at a far lower cost than US\$750 per pill, though indicating this was not widely known (presumably for reasons of commercial confidentiality):

The WAC [wholesale acquisition cost] is only the published price and does not reflect the actual net cost of Daraprim or any other drug to patients, hospital, health plans or government programs. Significant discounts or rebates are customary, or often mandatory, but are not typically disclosed to the public. The actual net price of Daraprim ranges from $\$ 0.01$ (one cent) per pill ('penny-pricing') to $\$ 750$ per pill. Less than a quarter of the sales occur at the higher-end of this range. (Turing Pharmaceuticals, 2016: 3)

Retzlaff then listed several means Turing had used to make 'Daraprim available to all patients, regardless of the ability to pay' (Turing Pharmaceuticals, 2016: 3-4). Earlier, she had argued that securing funds to improve access was one reason for raising the price. Hence, like Shkreli, she sought to legitimise the company's conduct by denying the price reduced access; indeed, she suggested access was enhanced because it facilitated price discounting. Retzlaff also emphasised Turing's role in disease awareness, talking of investment in a team to educate health professionals to increase early diagnosis. Such campaigns, as noted, not only encourage diagnosis (potentially a health benefit) but also increase sales.

Retzlaff next invoked R\&D costs to justify the rise as had Gilead's Gregg Alton. This is Sykes and Matza's 'denial of responsibility' legitimising technique, embodied in the assertion that such costs constrain companies to charge high prices. However, since Turing, like Gilead, had not paid the main development costs, but just those of purchasing the rights and of manufacturing and marketing it, they emphasised the costs of developing other drugs, so claiming further health benefit. Early in her testimony, Retzlaff stated that one of Turing's business goals was to fund R\&D into alternative treatments for toxoplasmosis and other diseases neglected by the industry. A November 2015 press release, before her testimony to the Committee but after the scandal broke, listed some of Turing's R\&D work and put a new drug for toxoplasmosis at the head, and then another for a rare disorder of the nervous system (Turing Pharmaceuticals, 2015). Yet the list included a drug to treat posttraumatic stress disorder, followed by another for epilepsy, hardly rare or neglected diseases.

Retzlaff also asserted that Turing was a research-based company 'committed to innovation and reinvests 60 percent of its net income from the sale of Daraprim into research and development - a figure that far exceeds industry standards' (Turing Pharmaceuticals, 2016: 6). Here and elsewhere the word innovation when used by the industry stands as a signifier for health benefit. However, it is unlikely that Turing's R\&D expenditure had, in its brief life, been above average. 


\section{Case 3: Valeant and Nitropress and Isuprel}

The third case prompting a US Government investigation occurred in April 2015, when Valeant Pharmaceuticals purchased two branded, off-patent drugs used to treat heart conditions, Nitropress and Isuprel, from Marathon Pharmaceuticals, and increased the US prices by 212 per cent and 525 per cent respectively. The acquisition was one of several that had greatly expanded Valeant since 2008, when Michael J Pearson became Chief Executive. Again, there was adverse publicity about the sharp price increases and Pearson was summoned to testify, this time before a Senate Special Committee on Aging. Like Shkreli, he had to be subpoenaed before attending, but did not then refuse to testify. However, when he appeared in April 2016, he had agreed to stand down as Chief Executive once a replacement was found, not least because Valeant's share price had fallen by 80 per cent.

Pearson initially adopted a conciliatory manner; he admitted making mistakes and expressed regret for some of his actions:

In particular, the company was too aggressive - and I, as its leader, was too aggressive - in pursuing price increases on certain drugs. Let me state plainly that it was a mistake to pursue, and in hindsight I regret pursuing, transactions where a central premise was a planned increase in the price of the medicines, such as our acquisition of Nitropress and Isuprel from Marathon Pharmaceuticals. (Valeant, 2016: 1)

At the same time there was a strong emphasis on what Valeant was doing to respond to concerns about the price rises. Like Retzlaff, Pearson sought to legitimise the rises by denying access was restricted - a denial of injury - and talked of a volume-based rebate programme for hospitals, and one with Walgreens (a major US pharmacy chain) to "provide substantial savings for patients' (Valeant, 2016: 2). Significantly, in May that year, when the investigations was still ongoing, this programme was extended, so providing some recognition of the critics' case.

There was also the usual denial of responsibility, justification emphasising the constraint of high R\&D costs, again for future drugs:

Valeant's US pharmaceutical R\&D spending was about $8 \%$ of our US branded pharmaceutical revenue last year, and we estimate that total US R\&D spending will be about $\$ 4000$ million in 2016. We have 43 R\&D facilities and approximately 1,000 R\&D employees worldwide. (Valeant, 2016: 2)

Significantly, the investment was said to be distinctive in focusing not on open-ended research but on realising results from R\&D: 'In the past two years, Valeant has launched 76 new prescription drugs, generic drugs, medical devices, and other products in the United States' (Valeant, 2016: 2) - here the justification combines with an affirmation of health benefit.

Having sought to legitimise the price increases, Pearson's tone became more assertive as he outlined the company's business approach and the centrality of acquisitions to it:

We have also tried to learn from the trends that have invigorated the technology sector by supplementing our internal R\&D with acquisitions, licensing agreements, and partnerships with innovative start-ups and academic research institutions. Some of the most exciting 
innovations and developments in the healthcare sector are occurring in these settings, rather than in the large, bureaucratic research laboratories of the big pharmaceutical companies. (Valeant, 2016: 3)

Valeant, he suggested, could bring such products to the market 'faster and more efficiently' (Valeant, 2016). Here, too, while emphasising the costs of innovation via acquisitions, we can see the legitimising technique that claims the potential health benefits of the company's activities.

\section{Case 4: Mylan and EpiPens}

The final case examined here is Mylan's marked US price rise for its EpiPens: from about US $\$ 100$ for one pen in 2008 to around US\$600 for a two-pen pack in 2016 (single pens were no longer available). The cost of the same pack in France was US\$100 and in Germany US\$200, indicating that the US price was inflated. The pens, with a shelf-life of around 1 year, provide a means of delivering epinephrine (adrenaline) by auto-injection to individuals experiencing a severe allergic reaction termed an anaphylactic shock, leading to difficulties with breathing, and occasionally fatal. Epinephrine is not itself patented, but the method of delivery - the EpiPen - is, and was acquired by Mylan in 2007, when it took over the generics business of German Merck.

Mylan's hiking of the price for EpiPen again caught the attention of the media and led to a hearing by the House of Representative's Committee on Oversight and Reform - the committee that had investigated Turing. Mylan's testimony was given by Heather Bresch, the Chief Executive, who also faced questions from Committee members. After giving some details about her background and experience, she started with the usual legitimising claim about the health benefits Mylan had brought: 'what's also extremely important is the tremendous amount of good Mylan has done for millions of patients in the U.S. and around the world' (Committee on Oversight and Government Reform, 2017: 19). Later she added, 'For millions of families, the presence of an EipiPen Auto-injector in a purse, briefcase, backpack or medicine cabinet is a source of enormous comfort and an invaluable insurance against a potential tragic event' (Committee on Oversight and Government Reform, 2017: 20). She also claimed that before Mylan's acquisition, fewer than 1 million of the 43 million people at risk had access to an epinephrine injector, and that estimates indicated 'that anaphylaxis was causing 1,500 deaths annually' (Committee on Oversight and Government Reform, 2017: 17). No source was given, but this was presumably a global figure since Ma and colleagues (2014) estimated 186-225 US deaths annually.

The theme of access was also contained in her second argument - the familiar denial that price limits access because of the company's discounts. Here, her strategy was not unlike that of Nancy Retzlaff with Daraprim: to emphasise how many individuals could get the drug for free or at a discount. Bresch asserted 'I've spent my entire career working to break down barriers, expand access to high quality medicines and lower healthcare costs' (Committee on Oversight and Government Reform, 2017: 19). Later she was more specific claiming:

We have made great strides in providing access to EpiPens in public places, starting with schools. In the last 4 years alone, Mylan provided 700,000 free EpiPens to more than 66,000 schools across America with no strings attached. Our pens were used hundreds of times, including on many children who had no known allergies. (Committee on Oversight and Government Reform, 2017: 18) 
Not surprisingly, Bresch also used the legitimising technique of the constraint of R\&D costs:

As primarily a generic pharmaceutical company, we must invest heavily in research and development and manufacturing in order to produce billions of doses and bring hundreds of new products to market every year. This year for example, we will spend approximately $\$ 1.2$ billion in $\mathrm{R} \& \mathrm{D}$ and manufacturing facilities, or roughly $\$ 3$ million a day. (Committee on Oversight and Government Reform, 2017: 19)

None of the Committee challenged her on the value of EpiPens. Instead, they focused on company spending that they considered had pushed up the price charged. In particular, they challenged her on the size of her salary. One commented, 'Ms Bresch made \$18,931,068 in 2015. I suppose when you get to salaries at that level that we're talking about, it's easy to forget an extra $\$ 931,000$. But the greed is astounding. It's sickening. It's disgusting' (Committee on Oversight and Government Reform, 2017: 33).

The Committee also questioned the company's spending on marketing: 'and so according to these documents, you spent $\$ 97$ million on marketing in 2015 alone, and that is a huge amount, and that's what the documents say' (Committee on Oversight and Government Reform, 2017: 27). Bresch defended this spending, emphasising the value of increasing disease awareness:

we've done quite a bit on just anaphylaxis itself, that because there was such a low awareness of even what anaphylaxis was. Over the last 8 years, the ability to really be able to educate about not only is anaphylaxis something that is obviously life-threatening, but we now know that at least 25 to 30 percent of the time, when someone goes into anaphylaxis, they've never had an allergy before, whether a child or adult, which really drove our need to want to get it in public places. (Committee on Oversight and Government Reform, 2017: 27)

We can see here how promulgating disease awareness becomes the acceptable face of high spending on marketing that is designed to generate product demand.

The Committee further expressed some concern about the FDA's rejection of Teva's application for a generic version of the pen - with one member implying Mylan had played some part in this. Significantly, however, Bresch reported that Mylan itself were introducing a generic version for half the price - an interesting echo of Turing's action. Indeed, in three of the four cases examined here the companies either reduced their prices significantly (Turing and Mylan) or introduced further rebates (Valeant). And Mylan also had to agree in August 2017 to pay US\$465 million to settle claims that they had violated the False Claims Act by wittingly misclassifying the EpiPen as a generic drug to avoid paying rebates primarily owed to Medicaid (Department of Justice, 2017).

\section{The force of the legitimising techniques}

This analysis of four cases in which companies' prices were challenged highlights the typical claims, often inflated, that companies make in defence of the prices for drugs. It identifies three key legitimising techniques they use as tactical devices to try to ensure that their actions are seen as consistent with society's moral standards. These are set out in Table 1. 
Table 1.

Legitimising techniques used to justify high prices.

\begin{tabular}{ll}
\hline Typical claims & Legitimising technique \\
\hline 1.The medicine in question has considerable value & $\begin{array}{l}\text { Affirmation of health } \\
\text { benefit }\end{array}$ \\
$2 \begin{array}{l}\text { Access is not restricted by price because of extensive discounts } \\
\text { Denial of injury }\end{array}$ \\
$\begin{array}{ll}\text { Pharmaceutical R\&D is very expensive so necessitating high } \\
\text { prices }\end{array}$ & \begin{tabular}{l} 
Denial of responsibility \\
\hline
\end{tabular}
\end{tabular}

R\&D: research and development.

Although the Committees' final reports in all the four cases were critical and the members were clearly not convinced by the explanations offered, the companies were drawing on wellestablished repertoires widely used across the industry to justify prices, and such legitimations have considerable force. There are three key reasons why this is so. The first is that, as already suggested, companies' claims typically have some basis in truth. Consider, for instance, Gilead's claims about Sovaldi. The drug was proving very effective as a treatment for hepatitis $\mathrm{C}$ and its claims were probably not significantly exaggerated. Similarly, EpiPens had proved a convenient means of delivering epinephrine to those in anaphylactic shock, though there is evidence that they do not always work (Edney, 2017), and Mylan's claims about the value of their wide-scale distribution were probably somewhat exaggerated. Yet, such arguments would not be so effective if they did not contain an element of truth.

More generally, since some medicines have undoubtedly provided significant health benefits - painkillers and antibiotics are obvious examples - the recognition of this is readily extended to new drugs by the public, professionals and governments. This is in part a consequence of the very high value individuals place on health and the considerable fear of ill-health and death. People mostly want to believe that medicines work, and in that respect belief in their value has an emotional foundation that can blind them to more precise details as to when, for whom and to what extent a specific drug is helpful, and such beliefs often extend to professionals and policymakers This, of course, is why the legitimising technique affirming health benefits is so important.

Claims regarding access also have an element of truth since companies do discount prices via arrangements with various bodies, so making their products somewhat more accessible, although this is very different from an overall price reduction. Moreover, spending on $R \& D$ for medicines can be very expensive, even though the costs are often exaggerated (Light and Lexchin, 2012; Prasad and Mailankody, 2017), especially where other companies or government bodies have funded much of the research. Hence the high prices are often not fully justified by a company's high R\&D costs.

The second key reason is that more precise information about the value of the industry's products and its costs is usually not readily available to the public, doctors or even governments. Consider, for example, data about effectiveness. Information about a drug's effectiveness, or its side effects, is hard to find, and mostly is not presented in a useful way. For instance, the tests of efficacy required before a drug is approved are often comparative so a drug can be approved if it performs as well, or slightly better, than its competitor, but this 
does not tell you how effective it is. A drug may be twice as effective as its comparator, but both may be relatively ineffective. There have been various attempts to measure health benefits more precisely, such as Quality Adjusted Life Years (QALYS), a measure of the impact on survival prospects combined with quality of life which is, for instance, used by the British National Institute for Health and Care Excellence (NICE) in assessing the costeffectiveness of medicines. A more meaningful measure for the public is the NNT - the number needed to treat - for instance, the number of individuals who need to take a particular drug for a year to avoid say one heart attack. Yet such data are not readily available to public or professionals, so it is hard for them to identify the extent to which the claims being made are exaggerated.

There is also a lack of detailed and easily available information about pharmaceutical companies' actual costs and spending and how prices are determined, including discounts provided to particular bodies. And in this, companies have the accepted cloak of commercial confidentiality. Moreover, while companies tend to emphasise R\&D costs (Light and Lexchin, 2012) they say much less about other areas of spending that push up prices, such as that on executive salaries, share buybacks and marketing.

Third, there is the common reluctance of governments to challenge the industry's practices very forcefully, including on pricing, unless there is extensive public disquiet as in the four cases considered here. Since governments are usually major funders and providers of healthcare in which medicines play a vital role, it might be assumed that they would seek to curtail drug prices and there are certainly some efforts to do so (Ewbank et al., 2018), but these are often more limited than might be expected, despite, for example, general public disquiet in the United States about medicine prices (KFF, 2019). One reason is that because of their role in funding healthcare, governments come under considerable pressure from the very active lobbying in which companies often engage (Jorgensen, 2013). For instance, extensive lobbying helped to ensure that there were no major constraints on the price of drugs under the US Obamacare arrangements (Brill, 2015). Company lobbying was also crucial in the delay in intervention in the scandal over high levels of opioid-prescribing in the United States (McGreal, 2018). Governments are especially susceptible to such pressure and blandishments when companies' activities are located in the country, and contribute to the economy by raising gross domestic product (GDP), increasing exports and providing an important source of jobs (ITA, 2016). Governments may also face public pressure to ensure reasonable access to medicines regardless of cost, as with the pressure on the UK government from patient groups to make new, expensive cancer drugs available on the NHS. Moreover, the industry's emphasis on its adherence to moral standards and codes of conduct helps to convince the public, health professionals and governments of the propriety of its practices.

\section{Conclusion}

Pharmaceutical companies use three main legitimising techniques as tactical devices to justify the high prices of drugs. The first affirms the considerable health benefits of specific drugs and of medicines more generally and encourages a belief in their decisive role in the individual's and the population's health; the second seeks to deny that high prices are undermining access - a denial of injury also visible in the common practice of downplaying the harms medicines generate; the third suggests prices are constrained by, and are a product of, the alleged high financial costs to the industry of developing new drugs - a denial of responsibility. All three involve ways of trying to ensure that companies' pricing practices based on their economic interests are not seen as breaking society's moral standards - the 
moral economy in which the industry operates. Consequently, these techniques play a vital role in helping to defend the industry from its critics.

The techniques have particular force, not only because they contain clear elements of truth, but also because most people, whether lay or professional, lack the necessary information or motivation to assess the accuracy of the claims involved, often thinking only in broad terms of the benefits medicines can bring. It is reasonably easy, therefore, for pharmaceutical companies to make exaggerated claims about the health benefits of drugs, the relative ease of access to medicines and the costs of their production, since such claims cannot readily be challenged. And governments, which potentially have the most power to challenge them, are mostly rather reluctant to do so because of their direct interests in the industry as a source of productive activity, employment and taxation, and because of the extensive lobbying in which the industry engages.

Identifying the legitimising techniques used by the industry and their force can help to increase awareness and understanding of how companies seek, often quite successfully, to maintain a positive image of their activities in very skilful ways that are not easy to challenge. Yet, identifying how the techniques are used to defend the industry against possible criticisms may facilitate challenges to them. Recognising them as legitimising devices encourages a more careful examination of the claims and of the factors that underpin industry practices. In the case of prices the four Congressional investigations show how attention can be given to the many other factors that push up prices, such as high spending on executive pay and advertising, the role of market manipulation and the desire to maximise revenue. Indeed as the investigations highlight, it is primarily governments that have the power, if not always the willingness, to secure the necessary information to expose the industry's practices, including on pricing, and to seek to change them, yet too often are reluctant to do so.

\section{Funding}

The author(s) received no financial support for the research, authorship and/or publication of this article.

\section{ORCID iD}

Joan Busfield 1 https://orcid.org/0000-0002-9377-1909 


\section{References}

Abraham J (1995) Science, Politics and the Pharmaceutical Industry. London: UCL Press.

Abraham J and Reed T (2001) Trading risks for markets: The international harmonisation of pharmaceuticals regulation. Health, Risk \& Society 3: 113-128.

Alton G (2016) Re: Betting on hepatitis C: How financial speculation in drug development influences access to medicines. British Medical Journal 354: i3718.

Angell M (2005) The Truth about Drug Companies. New York: Random House.

Brill S (2015) America’s Bitter Pill. New York: Random House.

Committee on Oversight and Government Reform (2017) Reviewing the Rising Price of EpiPens. Washington, DC: US Government Publishing Office.

Davis C and Abraham J (2013) Unhealthy Pharmaceutical Regulation. Basingstoke: Palgrave Macmillan.

Department of Justice (2017). Mylan agrees to pay $\$ 465$ million to resolve False Claims Act liability for underpaying EpiPen rebates. Available at: https://www.justice.gov/opa/pr/mylanagrees-pay-465-million-resolve-false-claims-act-liability-underpaying-epipen-rebates

Dumit J (2012) Drugs for Life. Durham, NC: Duke University Press.

Edney A (2017) EpiPen failures cited in seven deaths this year, FDA files show. Available at: https://www.bloomberg.com/news/articles/2017-11-02/epipen-failures-cited-in-seven-deathsthis-year-fda-files-show

Ewbank L, Omojomolo D, Sullivan K, et al. (2018) The Rising Cost of Medicines to the NHS. London: King's Fund.

Fellner C (2012) Ipilimumab (Yervoy) prolongs survival in advanced melanoma. Drug Forecast 37: 503-511, 530.

Gilead (2018) US patient access. Available at: http://www.gilead.com/responsibility/uspatient-access

Goldacre B (2012) Bad Pharma: How Drug Companies Mislead Doctors and Harm Patients. London: Fourth Estate.

GOV.UK (2016) CMA fines pharma companies $£ 45$ million. Available at: https://www.gov.uk/government/news/cma-fines-pharma-companies-45-million

Gupta H, Kumar S, Roy SJ, et al. (2010) Patent protection strategies. Journal of Pharmacy and BioAllied Sciences 2: 2-7.

Healy D (2012) Pharmageddon. Berkeley, CA: University of California Press. 
IGEA Hub (2017) Top 10 Pharmaceutical Companies. New York: IGEA Hub.

International Federation of Pharmaceutical Manufacturers and Associations (IFPMA) (2012) Code of Practice. Geneva: International Federation of Pharmaceutical Manufacturers and Associations.

ITA (2016) Top markets reports: Pharmaceuticals. Available at: http://trade.gov/topmarkets/pdf/Pharmaceuticals_Executive_Summary.pdf

Jorgensen PD (2013) Pharmaceutical, political money and public policy. Journal of Law, Medicine \& Ethics 41: 561-570.

KFF (2019) Public Opinion on Prescription Drugs and Their Prices. Oakland, CA: Kaiser Family Foundation.

Kinch M (2016) A Prescription for Change. Chapel Hill, NC: University of North Carolina Press.

Lazonick W, Hopkins M, Jacobson K, et al. (2017) US Pharma's financialized business model. Working Paper, Institute for New Economic Thinking, New York.

Light DW and Lexchin J (2012) Pharmaceutical research and development: What do we get for all that money? British Medical Journal 345: e4348.

Ma L, Danoff TM and Borish L (2014) Case fatality and population mortality associated with anaphylaxis in the United States. Journal of Allergy and Clinical Immunology 133: 10751083.

McGreal C (2018) American Overdose. London: Faber \& Faber.

Morris LD (2016) The moral economy of austerity: Analysing UK welfare reform. The British Journal of Sociology 67: 97-117.

Moynihan R and Cassels A (2005) Selling Sickness. Crows Nest, NSW, Australia: Allen \& Unwin.

Prasad V and Mailankody S (2017) Research and development spending to bring a single cancer drug to market and revenues after approval. JAMA Internal Medicine 177: 15691575 .

Ramsey L (2015) A pharma CEO tried to defend his decision to jack up the price of a critical drug by 5,000\% - and it backfired. Available at: http://uk.businessinsider.com/martin-shkrelidefends-daraprim-price-2015-9

Roy V and King L (2016) Betting on hepatitis C: How financial speculation in drug development influences access to medicines. British Medical Journal 354: i3718.

Senate Committee on Finance (2015) The Price of Sovaldi and Its Impact in the US Health Care System. Washington, DC: US Government Publishing Office. 
Sykes GM and Matza D (1957) Techniques of neutralization: A theory of delinquency. American Sociological Review 22: 664-670.

Thompson EP (1971) The moral economy of the English crowd in the eighteenth century. Past \& Present 50: 76-136.

Turing Pharmaceuticals (2015) Press Release: Turing reduces cost of Daraprim. Available at: https://www.turingpharma.com/press-releases/15/turing-reduces-cost-of-daraprimregpyrimethamine/

Turing Pharmaceuticals (2016) Testimony of Nancy Retzlaff chief commercial officer, Turing Pharmaceuticals before the House Committee on Oversight and Government Reform. Available at: http://docs.house.gov/meetings/GO/GO00/20160204/104374/HHRG-114GO00-Wstate-RetzlaffN-20160204.pdf

Valeant (2016) Statement of J Michael Pearson before the Special Committee on Aging. Available at: http://www.aging.senate.gov/imo/media/doc/SCA_Pearson_4_27_16.PDF

\section{Author biography}

Joan Busfield is a Professor of Sociology at the University of Essex. Initially trained as a clinical psychologist, she researches the areas of psychiatry, mental illness, the pharmaceutical industry and the use of medicines. 